\author{
(online) $=$ ISSN $2285-3642$ \\ ISSN-L = $2285-3642$ \\ Journal of Economic Development, Environment and People \\ Volume 9, Issue 4, 2019 \\ URL: http://jedep.spiruharet.ro \\ e-mail: office jedep@spiruharet.ro
}

\title{
Engagement of older persons in cultural activities: importance and barriers
}

\author{
Mihaela Ghenţa ${ }^{1}$ and Elen-Silvana Bobârnat ${ }^{2}$ \\ ${ }^{1,2}$ National Scientific Research Institute for Labour and Social Protection
}

\begin{abstract}
The aim of this article is to present the importance of cultural activities for older person, as well as of the barriers related to engagement in such activities. Cultural activities involvement is recognized as a way to promote the social participation of older persons and thus it contributes to a better social inclusion of these persons. The first part of the paper points the importance of cultural activities among older Romanians, while the last part of the article presents the factors that limit a more engagement in such activities for people of age 65 years and over.
\end{abstract}

Keywords: older persons, cultural activities, social inclusion

\section{JEL Codes: J14, J17}

How to cite: Ghenta, M., \& Bobarnat, E. (2019). Engagement of older persons in cultural activities: importance and barriers. Journal of Economic Development, Environment and People, 8(4), 6-12. doi:http://dx.doi.org/10.26458/jedep.v8i4.648

\section{Introduction}

Several studies emphasize that maintaining a high level of social participation at older ages is likely to have a positive influence on quality of life, emotional well-being and health [1], [2], [3]. In the studies conducted by WHO [4] it is admitted that social participation refers to engagement in recreational, socializing, cultural, educational and spiritual activities, and encouraging and motivating the participation of older people in cultural and social activities could contribute to reducing isolation among them.

The article analyses the phenomenon of cultural participation of the older persons in Romania. Cultural participation is a particular component of social inclusion. In the broad sense, culture is "opposite of nature" and it is created by society [5]. In the present research, the cultural participation is considered in

${ }^{1}$ Corresponding author. Tel.: + 403124069; E-mail address: ghenta@incsmps.ro 


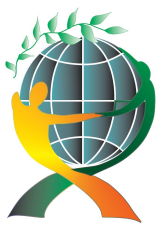

\author{
(online) $=$ ISSN $2285-3642$ \\ ISSN-L = $2285-3642$ \\ Journal of Economic Development, Environment and People \\ Volume 9, Issue 4, 2019 \\ URL: http://jedep.spiruharet.ro \\ e-mail: office jedep@spiruharet.ro
}

terms of involvement of older persons in activities like attending dance, theatre, opera performances, visits of historical sites, reading books or watching/listening of TV/radio programmes, etc. In the process of producing and disseminating the culture, the elderly can play the role of: creator, audience or transmitter of the culture [6], depending on how much they are integrated and valued by others.

\title{
2. The importance of involvement in cultural activities
}

The importance of involvement in cultural activities among older persons is related to their capacities to participate to the social, economic and cultural life of the community with good results in terms of social inclusion [4]. Social exclusion, viewed as a process, represents the reduction of participation of individuals/groups in different areas of life [7] and their separation from the core of ideas, attitudes and behaviors considered normal by society [8].

In 2017, in Romania, 20.6\% of the population of 65 and over are at risk of social exclusion as a result of severe material deprivation [9]. But social exclusion is a much multidimensional phenomenon [10]; its aspects can be grouped into several domains, namely: material deprivation, lack of access to fundamental rights, lack of social participation and lack of normative integration. Material deprivation refers to the financial capacity to procure material goods to meet basic needs. Also, it refers to the "problematic" debts categories of expenses destined to the basic needs (housing, maintenance, food, etc.) when most of the revenues are directed to cover them. Lack of access to fundamental rights refers to the situation in which individuals/groups face difficulties accessing health services, housing, education, social security etc., including waiting lists, financial impediments, physical infrastructure, etc. Lack of social integration refers to the reduced participation in formal and informal social networks, including leisure activities, insufficient social support and social isolation. Contacts with family members, friends and acquaintances, the existence of a person with whom the individual can discuss personal issues, membership in clubs and organizations, voluntary work and helping others improve this type of participation. Lack of normative integration means low compliance with society's norms and values, such as poor work ethic, abuse of the social assistance system, delinquent behaviour, and lack of community involvement. [7], [8].

Besides the benefits already mentioned, the involvement of the elderly in cultural activities also determines the dismantling of cultural stereotypes and the changing of the image of the elderly, thus improving their symbolic inclusion. The beneficial effects reflect on the identity inclusion also, by enriching elderly people with new identity dimensions, such as intergenerational transmitters of values and culture, influencers on media. [6], [11]

\subsection{Objectives}

The following research questions were addressed in this article:

- What is the importance of involvement in cultural activities in old age, among older Romanians?

- Which factors hinder the social participation through cultural activities of older persons living in rural and urban areas?

In order to answer to these questions we analyse data from the Special Eurobarometer 399 [12]. The database and the questionnaire are publicly available in the GESIS archive. The survey was coordinated by the European Commission and conducted by TNS on April 27-11 May, 2013. A probabilistic sample was used and a face-to-face questionnaire was applied. 


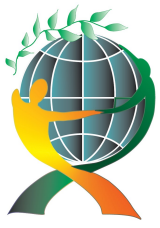

\author{
(online) $=$ ISSN $2285-3642$ \\ ISSN-L = $2285-3642$ \\ Journal of Economic Development, Environment and People \\ Volume 9, Issue 4, 2019 \\ URL: http://jedep.spiruharet.ro \\ e-mail: office jedep@spiruharet.ro
}

\title{
2.2. Involvement in cultural activities
}

The overall cultural practice index points to a rather low engagement of people aged 65 years and over, $59.7 \%$ of Romanians of this age being involved in cultural activities in 2013. Considering the view of [13] according to whom older people are excluded from cultural activities if they don't access these activities on a relatively frequent basis, we can state that older Romanians are social excluded. Most of the people aged 65 years and over from the rural area declared a low engagement in cultural activities (65.2\%) compared to approximately a half of the Romanians of the same age from the urban area (54.4\%). There is a direct link between the age of the respondent and the level of involvement in cultural activities, the respondents aged between 75-84 years old being less engaged in cultural activities: $73.8 \%$ of them declared a low involvement. As people grow older, they may experience a limitation of their capacity to perform activities due to physical and cognitive limitations and this could hinder their ability to involve in different kind of social activities.

Gender doesn't make a significant difference between respondents in terms of engagement in cultural activities. The ability to pay bills is also linked to some degree with participation in cultural activities as $51.8 \%$ of the older persons that experienced most of the times difficulties in paying the bills declared a low involvement in cultural activities, compared to $58.4 \%$ of those who have never experienced difficulties in paying the bills that declared a similar involvement. It is acknowledged that older persons are, all over the world, more exposed to the risk of poverty compared to the rest of the population, and in their case, poverty can target either a lack of income/insufficient material resources for a dignified life, or inadequate access to social, medical services, housing, transportation [11].

\section{The most frequented attended cultural activities}

Among the preferred cultural activities performed (at least one time) by older persons during the previous year before survey, were going to a historical site $(23.8 \%)$ or to a museum/gallery (11.1\%), followed by going to a concert (9.3\%). By far, the most preferred activity was watching or listening a TV or a radio programme, as over a half of the respondents aged 65 years old and over done such an activity, at least one time, during the last 12 month before the survey (54.6\%).

Going to a ballet/dance performance and cinema accounted no participation of respondents from rural areas. $44 \%$ of the respondents from rural areas prefer to see a TV or to listen to a radio programme at least one time in the year before the survey, compared to $64.9 \%$ of the respondents from urban areas. Over $10 \%$ from the older respondents in urban areas have engaged, at least one time during the year before the survey, in the following cultural activities: visiting a historical monument or site, followed by the visits to museums/galleries and going to concerts. There are limited possibilities for older persons in rural areas to participate in cultural activities and these reflect in a low involvement in any type of cultural activity. Another activity preferred both by older persons from rural and urban areas is reading books, as this is an activity that is not consuming important financial resources: $58.5 \%$, respectively $43.1 \%$ of the respondents have read a book at least once during the previous year of the survey. 


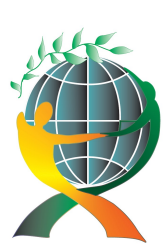

\author{
(online) $=$ ISSN $2285-3642$ \\ ISSN-L = $2285-3642$ \\ Journal of Economic Development, Environment and People \\ Volume 9, Issue 4, 2019
}

URL: http://jedep.spiruharet.ro

e-mail: office jedep@spiruharet.ro

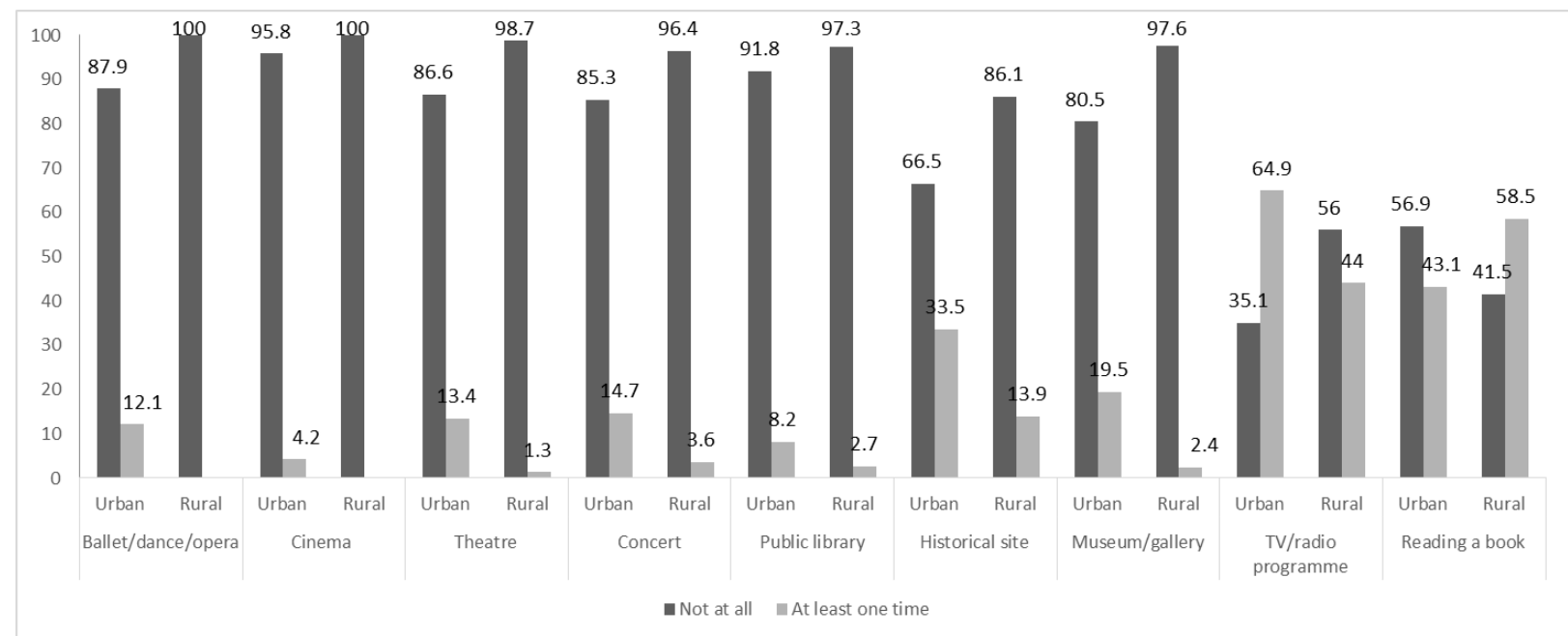

Fig. 1: Cultural activities engagement in the last 12 months, by area of residence and type of activity (65 year and over) Source: European Commission, Brussels (2016): Eurobarometer 79.2 (2013). TNS opinion, Brussels [producer]. GESIS Data Archive, Cologne. ZA5688 Data file Version 6.0.0, doi:10.4232/1.12577.

A higher age is linked to a lower involvement in cultural activities, as people aged 85 years and over are usually seeing TV programs or listen to radio shows or reading a book: $44.4 \%$ of the people of this age declared that they have read a book at least 5 times in the year before the survey and the same percentage had a similar cultural activity.

The ability to pay bills is also linked to the frequency with which the older people involve in cultural activities, as respondents who had difficulty in paying bills most of the times were less likely to engage in all sort of cultural activities, with the exception of reading books, visiting historical sites, watching/listening to TV/radio programs. $26.9 \%, 41.2 \%$, respectively $37.8 \%$ of those mentioned before involved at least once during the last year, in cultural activities.

Gender makes a difference, as women are more likely to visit museums or galleries: $13.3 \%$ of women aged 65 years and over involved more than five times during the year before the survey in such activities. On the other hand, men are more involved in activities like reading books ( $43 \%$ of them). Living in a bigger household affects the involvement in cultural activities with regard to historical sites visits, $20.6 \%$ of the older persons living in more than one person households engaged in such cultural activities at least one time during the year before the survey.

\title{
2.3. Barriers that limit the involvement in cultural activities
}

The main barrier that limited the engagement of older persons in cultural activities was the lack of interest, followed by the limited choice or poor quality. It has to be mentioned that in case of ballet/dance/opera performances or in case of attending theatre programmes, the limited possibility to cover the costs is another reason mentioned by older respondents.

As other international [13], [7] and national [11] studies emphasize, older people are more vulnerable to exclusion from social life, as well as from civic and cultural activities. In some cases the exclusion is due 


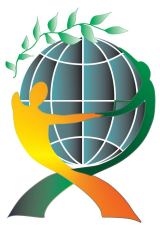

\author{
(online) $=$ ISSN $2285-3642$ \\ ISSN-L = $2285-3642$ \\ Journal of Economic Development, Environment and People \\ Volume 9, Issue 4, 2019
}

URL: http://jedep.spiruharet.ro

e-mail: office jedep@spiruharet.ro

not only to the limited financial resources, but as well due to education, previous life path or just because the older person remained alone and is not connected to a social support network.

\begin{tabular}{|c|c|c|c|c|c|c|c|c|}
\hline & $\begin{array}{c}\text { Ballet/dance/ } \\
\text { opera }\end{array}$ & Cinema & Theatre & Concert & $\begin{array}{l}\text { Public } \\
\text { library }\end{array}$ & $\begin{array}{l}\text { Historical } \\
\text { site }\end{array}$ & $\begin{array}{l}\text { Museum/ } \\
\text { Gallery }\end{array}$ & $\begin{array}{l}\text { TV/radio } \\
\text { programme }\end{array}$ \\
\hline Lack of interest & 34.4 & 38.2 & 33.6 & 33,2 & 37.8 & 28.5 & 33.3 & 27.2 \\
\hline Lack of time & 8.4 & 11.5 & 10.8 & 11.8 & 15.9 & 20.2 & 16.4 & 36.4 \\
\hline Too expensive & 18.9 & 13 & 18.8 & 15.5 & 4.4 & 14.2 & 14.2 & 3.6 \\
\hline $\begin{array}{c}\text { Lack of } \\
\text { information }\end{array}$ & 1.9 & 2.7 & 2.3 & 2.4 & 1.8 & 3.3 & 2.4 & 8.7 \\
\hline $\begin{array}{c}\text { Limited } \\
\text { choice/poor } \\
\text { quality }\end{array}$ & 30.2 & 29.6 & 29.5 & 30.6 & 28.4 & 27.7 & 27.3 & 14.3 \\
\hline Other & 6.2 & 5 & 5 & 6.4 & 11,7 & 6,1 & 6.4 & 9.9 \\
\hline
\end{tabular}

Table 1: Barriers to cultural activities engagement in the last 12 months, by type of activity (65 years and over) Source: European Commission, Brussels (2016): Eurobarometer 79.2 (2013). TNS opinion, Brussels [producer]. GESIS Data Archive, Cologne. ZA5688 Data file Version 6.0.0, doi:10.4232/1.12577.

The lack of interest is in a higher extent the main reason for a lower participation of older persons from rural area to different kind of concerts, compared with those from urban area (37.8\% of respondents aged 65 years old and over, compared with $28.8 \%$ in case of older persons from urban area). Another important reason that hinder the attending of concerts is the limited offer or poor quality (45.8\%). Going to a public library is less preferred by older persons from rural areas $(40.9 \%$ in case of respondents located in rural areas, comparative with $34.8 \%$ in case of persons from urban areas). Similarly, reading a book is more an option for older persons in urban areas $-23.5 \%$ compared with $42.5 \%$ in case of those from rural areas. In case of all type of cultural activities, the lack of enough financial resources to cover the participation is far more an important barrier for older women compared with men of the same age.

The ability of paying the bills doesn't make a significant difference between respondents in terms of reasons for not getting engaged in cultural activities. Both for those who experience most of the times difficulties in paying the bills as well as those who almost never have such difficulties, the main reasons for a low involvement in cultural activities remain the lack of interest and the costs associated with the activity. The lack of information is an important barrier for those old respondents who experience most of the times difficulties in paying the bill, only when it comes for watching/listening TV/radio programs. The affordability of cultural activities favors an increased participation of older persons, the cost of such activities being recognized as a barrier in the engagement in certain cultural activities [4]. The household composition influence the perceived barriers to cultural activities. Single old person households indicated the lack of interest as the major barrier in case of the majority of cultural activities, with the exception of theater and concerts attending.

Respondents 65 years and over use the Internet with the purpose of discovering, exploring, researching, conducting acquisitions, participating in cultural and social activities. At the national level, most seniors use the Internet for reading and information purposes. 


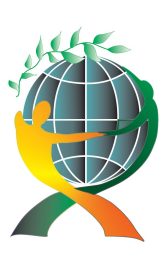

$$
\begin{gathered}
\text { (online) }=\text { ISSN } 2285-3642 \\
\text { ISSN-L = 2285 - } 3642
\end{gathered}
$$

Journal of Economic Development, Environment and People

Volume 9, Issue 4, 2019

URL: http://jedep.spiruharet.ro

e-mail: office iedep@spiruharet.ro

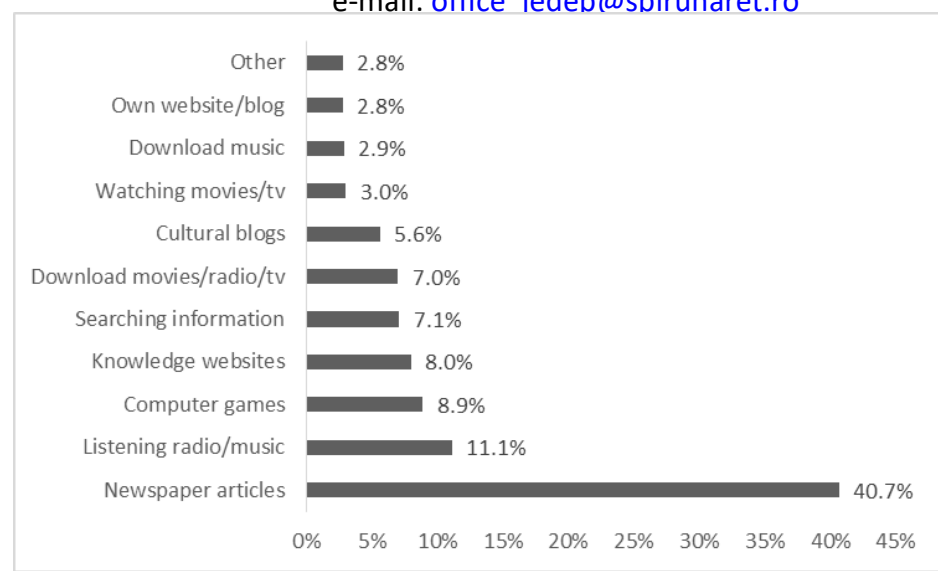

Fig. 2: Internet usage (65 years and over)

Source: European Commission, Brussels (2016): Eurobarometer 79.2 (2013). TNS opinion, Brussels [producer]. GESIS Data Archive, Cologne. ZA5688 Data file Version 6.0.0, doi:10.4232/1.12577.

\section{Conclusions}

Social participation in old ages has a positive influence on quality of life of older people. The studies concerning the involvement of older persons in cultural activities shows a rather low engagement of people aged 65 years and over, $59.7 \%$ of Romanians of this age being involved in cultural activities. Most of the people aged 65 years and over from the rural area declared a low engagement in cultural activities. As people get older, they tend to involve less and less in cultural activities due to limitation in performing daily activities.

The most preferred cultural activities performed (at least one time) by older persons during the previous year before survey, were watching or listening a TV or a radio programme, going to a historical site or to a museum/gallery followed by going to a concert. There are limited possibilities for older persons in rural areas to participate in cultural activities. The frequency with which the older people involve in cultural activities is related to the ability to pay bills.

The main barrier that limited the engagement of older persons in cultural activities was the lack of interest, followed by the limited choice or poor quality. The lack of information limits the watching/listening TV/radio programs for those with financial difficulties.

\section{Acknowledgements}

This work was published under the Nucleu Programme, supported by the Ministry of Research and Innovation (MCl), project number PN 19130401. (Această lucrare a fost realizată prin Programul-nucleu, derulat cu sprijinul MCl, proiect nr. PN 19130401).

\section{References}

[1] E. Rubio, A. Lazaro, A. Sanchez-Sanchez. Social participation and independence in activities of daily living: a cross sectional study. BMC Geriatrics. 2009, 9, 26: 1-11.

[2] J. Holt-Lunstad, T.B. Smith, J.B. Layton. Social Relationships and Mortality Risk: A Meta-analytic Review. PLoS Med. 2010, 7, 7: 1-20. 


\author{
(online) $=$ ISSN $2285-3642$ \\ ISSN-L = 2285 - 3642 \\ Journal of Economic Development, Environment and People \\ Volume 9, Issue 4, 2019 \\ URL: http://jedep.spiruharet.ro \\ e-mail: office jedep@spiruharet.ro
}

[3] M. Ghenţa, A. R. Matei, L. Mladen-Macovei, Ş.-C. Stroe. 2018. Calitatea vieţii persoanelor vârstnice dependente în România. Project report - Narrative reports of qualitative research (interviews and focus-groups disscusions). Not for public view.

[4] World Health Organisation, 2007. Global age-friendly cities: a guide, 2007. Available online at http://www.who.int/ageing/publications/Global_age_friendly_cities_Guide_English.pdf.

[5] F. Nollet. 2012. Elderly and cultural participation in society. Available online at http://www.enothe.eu/activities/meet/ac12/Appendix5.4.3.pdf.

[6] A. Jakubowska, E. Kłosiewicz, M. Mękarski. Changing the image of elderly people in Poland: the senior citizen as an important audience member and creator of culture, ENCATC Journal of Cultural Management and Policy //. 2015, Volume 5, Issue 1: 53-66.

[7] G. Jehoel-Gijsbers, C. Vrooman 2007. Explaining social exclusion: a theoretical model explaining social exclusion tested in the Netherlands. Available online at https://www.scp.nl/english/Publications/Publications by year /Publications_2007/Explaining_Social_Exclusion.

[8] K. Walsh, Th. Scharf, N. Keating. 2016. Social exclusion of older persons: a scoping review and conceptual framework. Eur J Ageing. 2017, 14: 81-98.

[9] Institutul Naţional de Statistică, Accesed at September 19th 2019.

[10] J. Millar. Social Exclusion and Social Policy Research: Defining Exclusion. In: Abrahams D., Christian J., Gordon D. (eds.) Multidisciplinary handbook of social exclusion research. 2007, 1-16. England: John Wiley \& Sons, Ltd.

[11] M. Ghenţa, A. R. Matei, L. Mladen-Macovei, Ş.-C. Stroe. 2018. Măsuri destinate creșterii incluziunii sociale a persoanelor vârstnice. Available online at http://www.mmuncii.ro/i33/images/Documente/MMJS/Transparenta/ 2019/01022019_Raport_stiint_masuri_incluz_pers_varstnice.pdf.

[12] European Commission, Brussels (2016): Eurobarometer 79.2 (2013). TNS opinion, Brussels [producer]. GESIS Data Archive, Cologne. ZA5688 Data file Version 6.0.0, doi:10.4232/1.12577.

[13] D. Kneale D. 2012. Is social exclusion still important for older people? Available online at https://www.bl.uk/collection-items/is-social-exclusion-still-important-for-older-people?mobile=on\#. 